Digital Press Social Sciences and Humanities

The Interpretation of Vai??ava Divinity Doctrine by The Maha Warga Bhujangga Waisnawa in Bali Island

Ni Kadek Surpi

Proceeding of 9th International Conference on Nusantara Philosophy (ICNP) Arndt Graf, Fitri Alfariz, M Rodinal Khair Khasri, Rachmad Hidayat, Rokhmat Sairah, Zaid bin Ahmad (eds) 


\title{
The Interpretation of Vaisnava Divinity Doctrine by The Maha Warga Bhujangga Waisnawa in Bali Island
}

\author{
Ni Kadek Surpi \\ Hindu State University I Gusti Bagus Sugriwa Denpasar, Faculty of Brahma Widya, Denpasar, Bali, Indonesia \\ email : dosen.surpiaryadharma@gmail.com
}

\begin{abstract}
Doctrinal issues are often a matter of contention between religious communities or beliefs. Therefore, to build a harmonious life, a bridge of dialogue and efforts to interpret doctrine is needed to create a spirit of appreciation amid different forms and religious expressions. The study is qualitative research in philosophy which examines the nature of the divinity of Vaisnava and the meaning of the doctrine of the divinity of Vaiṣnava by the Maha Warga Bhujangga Waisnawa in Bali. This research is also an effort to bridge the knowledge of Vaișnava divinity philosophy, which developed in the great Hindu civilization in India and Indonesia, which was built in the religious discipline of Visnu-Bhujangga Waisnawa worshipers. Bali has an old Vaisnava group inherited from the past that combines devotional service and mature philosophy. In the Hindu tradition, philosophy is essential and even strengthens the position of religion or belief. From a Hindu perspective, the Rgveda, the oldest religious literature in the world, together with the main Upanișads containing philosophical and religious thought, has provided the basis for developing philosophical and religious systems. The Hindu thinkers after Sankara built their philosophical system known as Bhakti-Vedānta or philosophy combining it with a thick system of devotional service, known as Vaișnava philosophy. The intellectual spirit combined with the devotional movement builds its strength in the body of Sanatana Dharma and has a significant influence on the survival and revival of Hinduism. The Vaișnava system holds that revelation and reason support each other, Vedānta is called theo-philosophy. Understanding God at the level of nature encourages thinking of respect for differences, the spirit of unity, and not fighting over differences in doctrine and different concepts. Dialogue in the realm of philosophy and theology will encourage a harmonious and mutually respectful life. This study concludes that the divine doctrine for Maha Warga Bhujangga Vaishnava is to live Vishnu at the same level of the essence as Brahman. Brahman is the highest reality, the God of religion, and the highest object of worship.
\end{abstract}

\section{Keywords}

Divine philosophy, Vedānta, Vaișṇava, Bujangga Waisnawa

\section{Introduction}

Maha Warga Bhujangga Waisnawa is a group of very old Viṣnu worshipers in the Nusantara. This becomes very interesting to study because this group experienced cultural imperialism and became incognito of Balinese customs and culture. However, the characteristics of philosophy and its features are still visible, although it is a bit vague in terms of doctrinal meaning. Vaișnava divinity philosophy is an essential part of the Vedānta and occupies a central place in the discussion of Darśana. Darśana, equated with philosophy, is a rational knowledge of God, supporting the belief and avoiding it from narrow views. (Sivananda 1998) asserted that philosophy is an analytical aspect of religion and an integral part of religion in India. It is further stated that philosophy is a sensible search for the nature of truth or Reality that provides solutions. Thus, philosophy is indeed needed to strengthen beliefs and give enlightenment to the implementation of Hindu teachings. A similar opinion is expressed by (Chari 2000) that religion and philosophy have become an inseparable part of Indian culture from the past. 
The philosophy of divinity is a branch of philosophy that investigates in depth the problem of divinity to produce knowledge of the nature of God as far as the human mind can reach. According to (Tjahjadi 2007), the divinity philosophy is thinking about God with an intellectual approach, which uses a philosophical system. People who adhere to a particular religion will add revelation in their process. So the philosophy of divinity is human thought with a rational approach to God. The pursuit of God through the mind has been a philosophical passion since 200 years ago. Reasoning God, the question of God is still the center of philosophical thought and the emergence of various understandings on the intellectual stage (Suseno 2007). (Leahy 1993) states that in English, the term Philosophy of God or Natural Theology is used for the philosophy of God. In Hinduism, the particular branch that studies divine philosophy is called Brahma Tattvajñāna.

Vaișnava It is one of the three major divisions of Hindu Dharma, alongside Saiva and Shakta. The objects of worship of Vaișnava Dharma are Vișnu, Krsna, and their extended incarnations such as Narayana, Rama, and so on. The main difference between the Vaiṣnava philosophy and other philosophies is in terms of achieving goals. Bhakti is the main path in this system (Knapp 1992). As a characteristic of the Puranas, Vaișnava is a Hindu division that glorifies Vișnu and his incarnations in the path of devotional service (Surpi et al. 2020). This article explains the common doctrines in Vaișnava philosophy and how these doctrines are interpreted by an older group of Vișnu devotees, namely Maha Warga Bhujangga Vaishnavas in Bali. There are differences in the effort to solve it, but a common thread can be seen.

The claims of revelation and reason have led to polarization, theology, and philosophy. The Vaișnava system holds that both are very important and mutually supportive, so Vedānta is called theo-philosophy (Tapasyānanda 2010). In Hamka's view (Hamka 2016), reason will determine the dignity of one's faith because with the increase in the height of the journey of reason, the more tools of knowledge used, in the end, the higher the dignity of one's faith and Islam. Hamka emphasized (Hamka 2017) that religion carried out only because of following (taklid) is very afraid of the test of reason. That person is swift to anger and accused of leaving the religion if someone expresses a different opinion from what he received from his teachers and ancestors. With Hamka's statement, it can be concluded that religion requires reason to increase its dignity. Vedānta uses both revelation and reason approaches and balances the two in the search for truth.

Hindu divinity, in general, uses theological and philosophical approaches simultaneously and does not contradict the two. According to the more satisfying typology to their hearts, people can study divinity through theology or philosophy. Likewise, the Vaișnava Godhead, which is part of the Vedānta, can be approached in the realm of philosophy and theology (Surpi 2020a). However, in describing the Vaișnava divinity, the authors use a philosophical approach or theo-philosophy because reason and knowledge are considered more acceptable.

Indeed, the Vaiṣnava divinity can be studied with both philosophical and theological approaches. Chari (Surpi 2019) divides the discussion of the Vaișnava divine philosophy, including the doctrine of Reality, the doctrine of the Individual Soul, the principle of the cosmic, the doctrine of means (bhakti-yoga), and the doctrine of ends (mokșa). While theology is more focused on discussing Viṣnu with the scope of Viṣnu as the Supreme Being, Viṣnu and the Goddess Srī, Vișṇu and His attributes, Viṣnu and His Incarnation, Viṣnu and jīva, Viṣnu and Nitya Vibhūti, Prapatti as a means of achieving Viṣnu, and Viṣnu as the goal. Supreme life. In addition, the Vaișnava religious discipline is a separate study.

Learning Hindu philosophy is actually an effort to brighten and even strengthen the unity of Hinduism, especially the use of reason and logic which is getting stronger today. The study of philosophy does not seem to have received good attention from Hindu institutions. Hindu philosophy is the breath of religion itself, needed by those who are typical Jnani, who need knowledge, just as the general public needs rituals to quench their religious thirst (Surpi, Widiana, and Wika 2021). Thus, the important side of this research is to provide a bridge between concepts and implementations in religion in order to build a spirit of mutual respect and work together to build a harmonious life.

\section{Methods}

This research is qualitative research that examines the Vaiṣnava divine philosophy. This research use text as the primary source to find out the mindset and chronology of Hindu thought in the past and trace the implications and implementation of the Bhujangga Vaishnava religious group in Bali. Vaisnava divinity is traced from several religious texts and the history of several kings, knights, and Vaishnava sages who came to Southeast Asia, including Java and Bali. Vaishnavas who entered Indonesia were the development of 
Vaishnava Gama, born during the Puranas in India. The Vaishnava concepts in Indonesia are closer to the Tantrayana, Sakta, and Vaishnava concepts that exist in Indonesia are indeed influenced by the Tri Murti Forced concept. This chronological understanding helps interpret the Vaisnava divinity thought traced from some religious texts and the history of the journey of many kings, knights, and Vaishnava sages who came to Southeast Asia, including Java and Bali. This understanding of chronology helps in interpreting the Vaisnava doctrine of divinity and the evolution of divine concept thought.

Data was obtained through literature study, documentation, interviews, and Focus Group Discussion (FGD). This study also uses the interpretation theory of Paul Ricoeur. Ricoeur seeks to bridge the problem of discourse going on for a very long time and has become a problem by Plato and Aristotle. Ricoeur started his discussion with the theme of language as a discourse. Ricoeur says (Ricoeur 2012) this is the first context in which the concept of discourse is known, that mistakes and truths are the affection of discourse and discourse to establish two basic signs, one noun and one interrelated verb in the synthetic form (meaningful) behind the well said a word.

The analysis used is the qualitative content, also known as Ethnographic Content Analysis (ECA), which combines objective content analysis with participant observation. The term ECA means that researchers interact with documentation materials or conduct in-depth interviews to put specific statements in the proper context for research.

\section{Result and Discussions}

\subsection{Philosophical activity in Hindu Dharma}

Reasoning God is familiar and has been done since ancient times in a particular branch that studies divine philosophy, namely the Brahma Tattvajñāna. (Edelmann 2015) Intellectual activity in Hinduism has been going on for a very long time. However, the term philosophy is not known in the Indian philosophical tradition, which got its fertile seeds in the Upanishads. The term close to philosophy (philosophy) in Western philosophy is Darśana (Aryadharma 2019). In general, Darśana means critical exposition, logical survey, or systems.

Furthermore, Radhakrishnan says that darśana signifies a system of thought acquired through intuitive experience, maintained and carried on by rational argument. But lately, to facilitate understanding, writers often use the word philosophy intending to facilitate understanding. (Steinkellner and Reyna 1973) Hinduism has a powerful philosophical and theological system with different learning and construction methods (Edelmann 2015). At this time, the intellectual is forced to conform to the vocabulary and genres of contemporary theological and philosophical conventions.

The activity of philosophizing has a perfect place in classical Indian philosophy and gave birth to so many commentators who continue to spin the wheel of knowledge in every era (Long 2012). Vedic knowledge has given rise to the tree of philosophical expertise as follows: (Surpi 2019) ; 


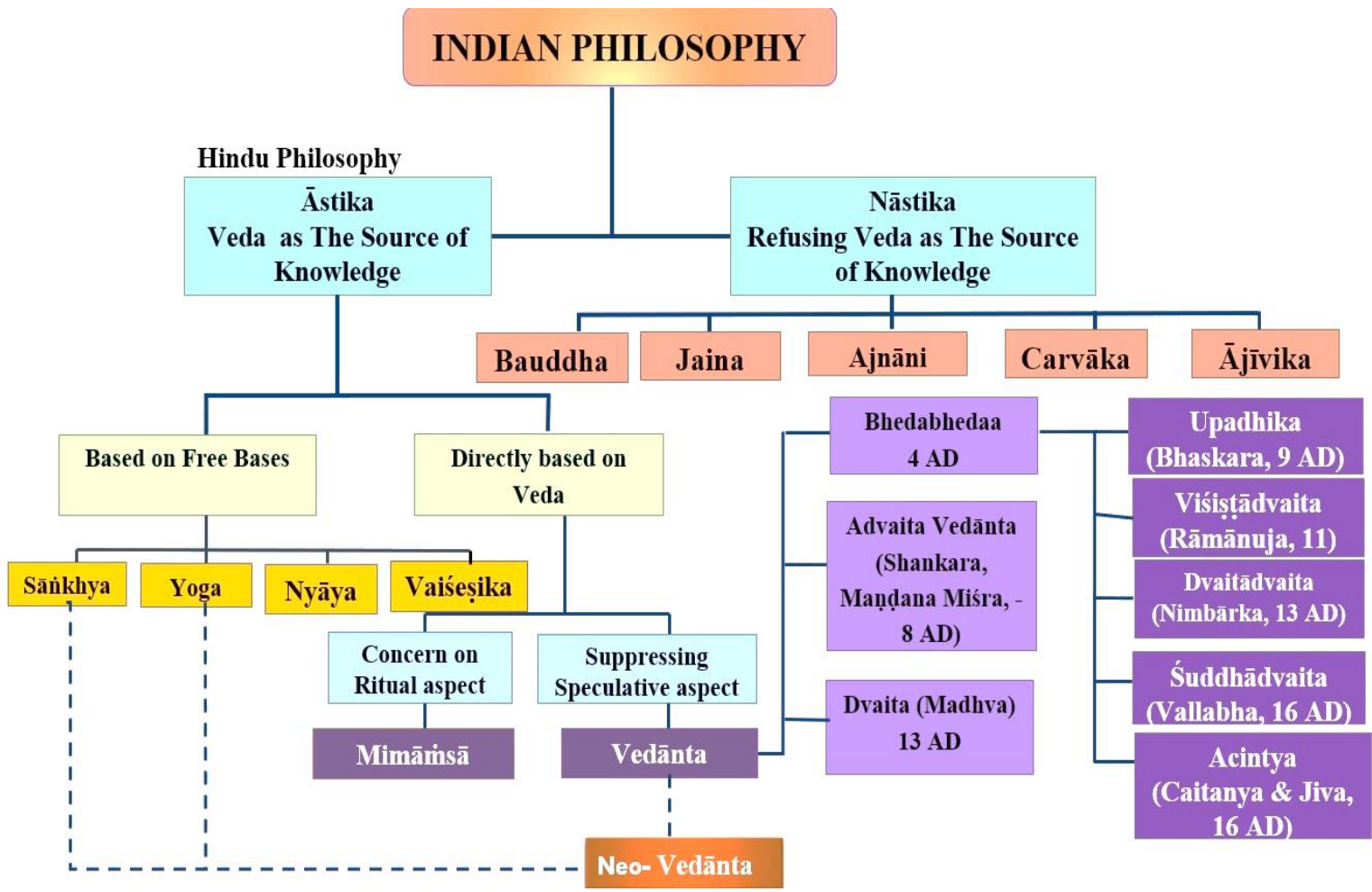

Fig. 1 Indian Philosophy Chart (Surpi et al. 2020)

Surpi et al. (2020) states that Indian thinkers and saints called Sad Darśana a Hindu philosophy otherwise known as Darśana āstra. The six Darśana āstras are (1) Purva Mimamsa founded by the spiritual master Jaimini, (2) Nyāya by the spiritual master Gautama, (3) Vaiseshika by the Canadian spiritual master, (4) Sānkhya by Bhagavan Kapila, (5) Yoga by the spiritual master Patanjali, (6) Uttara Mimāmsā (Brahma Sūtra) by Bhagavan Veda Vyāsa. So strictly speaking, what is meant by Hindu philosophy, Darśana āstra, namely the six orthodox systems, which recognize the Vedas as the supreme authority. Vedānta is a philosophical system that comes directly from the Vedas. That is, it acknowledges the authority of the Vedas while still relying on the power of reason and intelligence.

Vedānta is a philosophical system that comes directly from the Vedas. That is, it recognizes the authority of the Vedas while still relying on the power of reason and intelligence. (Chano and Surpi 2020) states that Vedānta comes from Veda and anta, meaning 'the final part of the Vedas.' (Sivananda 1998) says the term Vedānta means the end or essence and the Vedas. Sivananda further states that the Vedānta system was founded by Sri Vyasa, the avatara of Viṣnu, the son of Rsi Sri Parasara. Vedānta also means the design that comes from the Upanișads, Bhagavad-gitā, and Brahma-Sutras. These three are called Prașțana-trayā. (Smith, Olivelle, and Roebuck 2002) states that the Upanișad teachings were systematized for the first time around 500-200 BC by Rsi Badarayana, known as the Brahma Sutra (Aphorisms related to Brahman) or the Vedānta Sūtra.

From the well-known Vedānta philosophical system, there are several prominent teachers or philosophers namely Rāmānuja, Nimbārka, Madhva, Vallabha, and Caitanya. The five eminent teachers gave slightly different comments on the concept of God and several other doctrines (Surpi et al. 2020). But in general, the system that is built is called the Bhakti Vedānta philosophy or Vaișnava philosophy. Apart from the similarity of the philosophical system, its main feature is the exaltation of Viṣnu and his incarnation and the central discourse in his philosophy. This sub-system developed into a philosophical system, and an established religious tradition is known as Vaisnava Dharma.

Several researchers reveal that India's influence on Southeast Asia, including the Nusantara, has occurred in the very past. Meanwhile, (Munoz 2013) believes that contact between India and the Indonesian Archipelago happened in the middle of the 1st millennium BC. The antiquity of this exchange is supported by references to Southeast Asian countries in Indian literature dating to the 3rd century BC and by the discoveries of some Indian artifacts, such as the typical Indian roulette pot dating from 100-200 AD, 
from the Buni complex in West Java to Sembiran, the north coast of Bali Island (Patra 2014). This finding shows that these countries had regular trade contacts with India for a long time before the spread of Indian culture.

Over the centuries, Sanskrit became the language of inscriptions in South Asia at the beginning of the common era. Then it gradually took over and became the predominant language of prestige throughout the South Asian continent and most of Southeast Asia. It has been almost a thousand years that Sanskrit's rules have been in this enormous domain. This Sanskrit cosmopolis occurred between the years 300 and 1300 (Pollock 1996). Using the Sanskrit expression cosmopolis, Pollock draws attention to the political dimension of the spread of Sanskrit. One of the hallmarks of the Sanskrit cosmopolis, it is argued, is that Sanskrit became the primary instrument of political expression in governments in much of the South and much of Southeast Asia (Pollock 1996). Several reports indicate more than 1,250 inscriptions were found in Southeast Asian countries. Most of them speak Sanskrit. Champa, now known as Vietnam, has the oldest Sanskrit inscription known as the Vo-Chanh Inscription. The inscription tells about king Sri Maran. The words of Sri Mara Raja Kula were read very clearly. Although there is not much information about this King from other sources, Chinese historians assert that the Hindu kingdoms in Vietnam, Laos, and Cambodia began with Sri Maran. From a number of these inscriptions, more than 800 inscriptions are in Sanskrit, and currently, more and more inscriptions are being found (Sharan 2003).

Hinduism in Indo-Malay roughly follows the pattern of development of Hinduism in India. From the beginning of Hinduism until the 7th century AD, the teachings of Vaișnava (worship of Vișnu as the Supreme God) became the dominant teaching. From the 7th century, Shivaism (worship of Shiva as the Supreme God) became more popular. Shiva's teachings were embraced by many merchants, just as Buddhism and an extensive network of Viu settlements co-existed with Buddhist community settlements. For example, in Malay, Kota Kapur (Tarumanegara), it makes sense for Wiu and Buddhists to compete with each other (Manguin 2004).

The influence of vaișnava is also seen in the discourses of the kings in Java. In the history of the Javanese kings, there is an exciting thing, namely the discourse of Arjuna in the legitimacy of the Javanese kings in the Mataram dynasty. Arjuna is a Kshatriya, the central character of the Mahabharata, in which Krishna plays an essential role in the story. The discourses that developed about the genealogy of the Mataram kings as recorded in the Chronicle of Tanah Jawi and the History of Ancestral Dalem from Pangiwa Utawi Panengen confirmed the legitimacy of the power of the kings of the Mataram dynasty. The discourse conveyed that Panembahan Senopati and his descendants were not ordinary people but unique humans. Descendants of Arjuna and the prophet Muhammad (Aryadharma 2019).

The figure of Garuda Dewa, which is Vișnu's vehicle, is also influential in the community during the Hindu-Buddhist kingdom in the Archipelago. The mythological creature Garuda is one of the evidence of the Hindu cultural heritage that emerged in Indonesia. Garuda according to Hidayat, is a god in Hinduism and is believed to be a vehicle or vehicle for Lord Wișnu, one of the Trimurti or manifestations of God's form in Hinduism. In Indonesia, Garuḍa is known as Garuḍa Wiṣnu Kencana (GWK) and is told in a book or Adiparwa book. But besides being known as a mythological creature (Hidayat 2009).

Thus, vaișnava teachings do have a vast influence in Southeast Asia, including in Indonesia. Vaișnava teachings have been seen in the style of the kingdom, literature, architecture, art to influence the discourse of kings in Java. Vaișnava teachings have given shape and have had a significant influence in Southeast Asia since the early centuries AD.

\subsection{Doctrine in Vaișṇava Divine Philosophy}

\section{The Doctrine of Ultimate Reality}

The discussion of divine philosophy in the Vedānta always begins with Brahman, the Absolute Ultimate Reality, an absolute reality. (Mohanty 2018) asserts that philosophical inquiry into Brahman as the Ultimate Reality is the central theme of Vedānta. The Visistadvaitin's goal is a clear and tangible knowledge of the Saguna Brahman and its attributes, which are described as enshrined in the various Upanișads. The Vedānta philosophy carefully considers spiritual experience without compromising its integrity and systematically demonstrates the fundamental truth. The truth of the Vedānta is valid, impersonal, and eternal. It can be felt through consciousness when released from the imperfection of avidyā-karman. The philosophy of religion makes such intuitions understandable and judged in the light of Śruti.

Metaphysics, morals, and aesthetics are intertwined and related as a whole. They carry the nature of the First Cause as well as the Final Cause of all things. Brahmin is the totality of Reality and the home of all eternal values such as truth, goodness, and beauty. Vedānta defines the ontological nature of Brahman as 
Satya (Reality), jñāna (self-awareness), and Ananta (infinity). His ethical philosophy predicts amalatva (goodness) as the moral content of a Brahman being like Iswara. Aesthetics define Brahman as Sundara, beautiful, and anandamaya, full of happiness (Radhakrishnan 1924). The Upanișads have given humankind the highest philosophy, capable of bringing Brahman to the threshold of the highest Reality (KadekSurpi 2021). One of them, Kena Upanișad, proclaims the truth in the statement, such as the Ultimate Reality. Brahman is within you and not something we worship here in the world. God is the supreme being, and He is within you. The self that captivates the eye to see makes the ear hear. The function of the limbs and the mind feels emotions. Reason to understand the mind, it is the highest God and not what people worship in the outside world.

A true philosopher, Upanișadic observers are more concerned with finding a solution to a problem than trying to answer theological questions such as which personality of the gods is supreme (Stoker 2007). Therefore, the Upanișads describe Reality in general terms such as Sat, Ātman, Brahman, Para-tattva, Param-Jyotish, etc. In the Taittirìya Upanișad, it is stated: "That from which all these beings are born, who then, at birth they live, and which, when departing they unite, have the desire to know that; that is Brahman (Taittirīya Upanișad III.1)" (Harshananda 2009). It is on this text that the author of the Vedānta Sūtra defines Brahman as the originator of the creation, maintenance, and dissolving of the universe (Vedānta Sūtra, I.1.2). Thus, Brahman must be the primary cause of the universe's creation, maintenance, and dissolution as the ultimate metaphysical reality. In other words, (Chari 2000) that the Jagatkāranatva, or being the leading cause of the universe, is an essential criterion for accepting the ontological entity as the Ultimate Reality. By applying this criterion, the Vedānta Sūtra eliminates all other ontological entities. For instance, the individual (jīva) of the primordial cosmic matter (pradhāna) from the Sānkya system, such as the physical ākāśas, vital prānas, sunlight, etc., which prima facie appear to be the primary causal of the concept of this supreme Reality. So then the Jagatkāranatva becomes the distinguishing characteristic of the Supreme Personality.

The characteristic of the Upanișad, as described by the Taittirīya Upanișad, is the investigation of Brahman and is the keyword of the Brahma Sūtra. Namely athāto brahmajijñāsā (Brahma Sūtra 1.1) -"now, therefore, the investigation of Brahman" followed by the next sutra janmādyasya yatah- (Brahma Sūtra 1.2)-"Brahman is the all-knowing and all-powerful cause, from which comes the origin (i.e., nourishment and dissolution) of this world. (Vireśvarānanda 2002). The first two sūtra of the Brahma Sūtra stipulate that an investigation into Brahman should be carried out, for this helps liberation. Knowledge of Brahman leads to liberation. To gain knowledge of Brahman, He must possess some characteristics by which He can be known. Hence the discussion of Brahman becomes a central element in Vedānta philosophy. The doctrine of ultimate Reality is also a significant topic in Vaișnava philosophy.

The main questions in the realm of Hindu divine philosophy are; what is the proof of the existence of reality? What is the evidence for this Reality? Is it possible to prove the existence of Brahman or God with logical arguments? (Chari 2000) replies that according to the Nyaya philosophy, a Hindu philosophical system that emphasizes logic, it is possible to state it logically. Cosmological arguments based on the idea of causation have been adopted to prove the existence of God. Every definite effect has a cause, and the universe, which is a substantial effect, is produced by a creative agent called İśvara. Meanwhile, the Vedantins reject purely logical arguments because they cannot conclusively establish the Supreme Being as understood in the Upanișads. Moreover, it has encountered a logic error.

It is further stated that what logic can construct can also be refuted by the same method of reasoning, as the Mādhyamikas have done with the question of the existence of God. The author of the Vedānta sutras asserts that Tarka (logic) cannot be conclusive (Vedanta Sutra II.1.11). But this does not mean the Vedantins reject logical reasoning. They accept it, but it doesn't have to be the only means of proof because, in super-normal things like God or jīva, logical reasoning cannot build convincing evidence. So, in other words, Śruti or sacred literature must be taken as the final authority, and logical arguments must be adopted to support the scriptures (Surpi A 2020). This opinion is also supported by Brahma-Sutra 1.3 that sacred literature is a tool of true knowledge (Vireśvarānanda 2002). If there is any doubt about Brahman, Śruti is the only proof of Brahman. Brahman has no form, so it cannot be understood by direct perception. Moreover, in the absence of distinct characteristics, such as the smoke from his fire, He cannot be established by inference or analogy (upamāna). Therefore it can only be understood through sacred literature. 


\section{Brahman as the Supreme Entity}

The word used in the Upanișads to denote the Highest is Brahman. What is Brahman in the Upanișads? By taking the root of the verb $b r h$, which means 'to grow' etymologically, it means that which grows (brhati) and causes it to grow (brinmayati) (Surpi and Purwadi 2021); (Venkatesan 2018). (Radhakrishnan 1953) states brh mean growing, arising everywhere. These two epithets -brhattva and brhmanatva convey the primary meaning of the term brahman, which signifies that it is Brahman who has infinite greatness both in terms of its intrinsic nature (svarüpa) as well as its attributes (gunatah). These two attributes refer only to the Supreme Being (sarveśvara), not to an indistinguishable being (Nirviśeșa Brahma).

Śri Śańkara Brahman comes from the root word bṛhati, beyond, atiśayana, which means pure state (Radhakrishnan 1924). Another philosopher, Rāmānuja, states that the term Brahman denotes the Purusottama or Supreme Person who is essentially free from all imperfections (nirasta nikhila doșah) and possesses the attribute of infinite auspiciousness of unsurpassed excellence (Ananta -kalyaña -gunagunah). The concept of Purushottama as qualification by two specific attributes distinguishes Brahman from every other being like Caturmukha Brahmā and Rudra, the individual jivvas including the eternally free and even the nirguna and saguna Brahman of Advaita Vedanta, for none of these are truly liberated. From defects and has infinite attributes that are incomparable (srutaprakasika I.1.1). Thus, Vedanta commentators agree that Brahman, as the Supreme Person, cannot be compared with any other entity free from the defects or control of the three modes of nature (tri Guna). The Gods are declared bound by a specific nature not to be compared with this supreme person. Brahman is the identity of all fundamental polarities (Chaudhuri 1954).

\section{Brahman as God of Religion}

Brahman, as the God of Religion, requires a personal form. Identification of Brahman with Nārāyaṇa builds on the Upanișadic texts by adopting the interpretation principles laid down by Mimamsaka (Mimamsa adherents). According to them, when several terms are used in the same context in a passage, words that have a general meaning must also contain the meaning of a particular word. The terms Sat, Brahman, Atman, and Nārāyana, are used in the upanișadic passages in the same context to describe the cause of the universe by Brahman at creation. The Chandogya Upanișad, says "this, in the beginning, there was only Sat." The Aitareya Upanișad says, "All this was only Atman in the beginning.". whereas the Brihadāranyaka Upanișad states "everything was only Brahman in the beginning" (Long 2012). The three terms Sat, Atman, and Brahman refer to the entity's sole cause of the universe. In comparison, the Mahopanisad states that Only Nārāyana existed in the beginning.

Närāyana, in the view of the ordinary people, is mentioned as the name of a particular God. (Stoker 2007); (Chari 2000) asserts Based on the grammatical rules formulated by Panini, the term Nārāyana is treated as a specific name (samjna-pada) and is only applied to a particular entity and not to other entities like other general terms. The Taittiriya Nārāyana Upanișad clearly states that Nārāyaṇa is Para-Brahma, Nārāyaṇa is Para-tattva and Nārāyaṇa is Paramatma. Nārāyaṇa is not just the name of the God of a specific system, which Westerners call a sect. Nārāyana is a term that implies all the essential characteristics of the highest Philosophical concept of Reality. Etymologically Nārāyana is He who is the basis of the entire universe of Cit and Acit. Nara means the universe of living and non-living beings. Ayana means He who is the foundation, or He who is immanent in all. Just as the terms Viṣnu and Vasudeva have the same etymological meaning as Nara-yana, Brahman is also equated with these two names.

The critical point in this context is that the metaphysical Ultimate Reality is to be understood as the Supreme Person (Purușottama). This can be justified philosophically. This other concept of Reality as a transcendently indistinguishable being cannot have a causal relationship with the universe itself. Accepting such a theory bridges the gap between religion and philosophy because the Personality of God of faith is not fundamentally and cannot be distinguished by the philosophy of Ultimate Reality.

Indian philosophy teaches that humans have a purpose and even the highest purpose in life, summon bonum, with the terms Mokșa, Mukti, Nirvana, Kaivalya, and Apavarga. Philosophy is not a dry thinking activity but the activity of thinking to achieve self-liberation from all forms of worldly shackles. That all knowledge, work, worship, etc., are meant for the attainment of the highest goal according to Indian tradition. Eastern view (India/Hindu) that intellect (buddhi) is a precious gift for humans, allowing humans to direct their lives in the light of knowledge. The Upanișads include jñāna as one of the essential elements in overcoming the suffering of attaining liberation. 


\subsection{The Understanding of the Vaișnava Divinity Doctrine by Warga Bhujangga Waisnawa}

The meaning of the Vaișnava Divinity doctrine by Bhujangga Vaishnavas is unique. It may even be the only Vaișnava group in the world that interprets the Vaiṣnava doctrine differently. Following the decision of Mahasabha Maha Warga Bhujangga Vaishnava in 2015 regarding strengthening Vaishnava identity, it is stated that Bhujangga Vaishnavas are a group that worships God in the form of Vișnu or the personification of Narayana. Thus, it means followers of Vaishnava ideology, namely the teachings of Bhakti Yoga; devotion to Wișnu. The word Vaishnava is interpreted as an incarnation of Vișnu, so that in this concept, it is ideological, anyone who believes in Vaishnava teachings. In this determination to strengthen identity, it is stated that followers of Vaishnava teachings include ideological and biological citizens. However, in the evolution of worship in Bali, it is considered part of the concept of Saiwa Siddhanta in Indonesia. Bhujangga Vaishnava as teaching or ideology refers to Hinduism, Sanatana Dharma whose teaching material is Chess Veda and Pancama Veda, Vedanta Sutra Bhagavata Purana, Ithiasa, and other forms of transformation in the form of lontars in Bali, which contain teachings and teachings. Values about the existence of Lord Vișnu or Narayana (Surpi 2019). Thus Vaishnavas practice the teaching of Bhakti to Wișnu and all forms of activity with the ultimate goal of reaching Wișnu, strictly speaking, that the ultimate goal of this association is attaining Wișnu by practicing the teaching of devotional service. This supreme goal is very similar to the Vaisnava teaching, which aims to achieve the Wișu realm as the highest form of happiness.

In its history in Bali, the Bhujangga Waisnawa group experienced what is known in social theory as Cultural imperialism or cultural imperialism. There is pressure and efforts to eliminate identity. Thus, about the identity of Bhujangga Vaishnavas, including the emphasis that Bhujangga Vaishnavas are not worshipers of Vișnu and are not associated with a group that has a biological relationship with several Rsi, including Rsi Markandeya. The cause of this pressure is competition between groups in Bali and the wrong assumption from some people about the existence of Maha Warga Bhujangga Waisnawa. Following the form of organizational imperialism (cultural domination, cultural coercion, and cultural fragmentation), and referring to the theory of Neo-functionalism, which provides an opportunity for discussion about cultural imperialism, the Bhujangga Waisnawa people have experienced imperialism in the form of cultural domination, coercion or fragmentation on the grounds of competition between groups (Surpi 2019). Bali is related to primordial power, namely the customary and cultural order, which is directly related to contested rituals for dominance. Therefore, this, in the long term, affects the doctrine. The understanding of the jiva and Brahman is similar to the Advaita philosophy. According to Advaita, the individual self (jīvātman) is not a real identity different from Brahman. Both are identical. Because of avidyā, ignorance, jīvā appears different from Brahman. What is understood as the Upaniṣad declaration is tat-tvam asi (Thou art that) (Gupta 2007).

In the Bhujangga Vaishnava tradition, the jiva is considered essential, and various rituals and sadhanas are performed to purify the soul. Soul purification is carried out in several methods, including the diksa procession for those who want to pursue the world of the priesthood. This shows the importance of the jiva and the evolution of consciousness in the Bhujangga Vaishnava tradition. However, it is not entirely the same as what is understood in the Vaiṣnava context in India. However, the essence is considered similar. The concept of jnana as an auxiliary tool of devotional service seems to be permeated by Maha Warga Bhujangga Vaishnava. Intensive learning pieces of evidence this among Bhujangga even since childhood. Bhakti teachings are also taught intensively. They are arranged in the Bhakti of Catur Guru lesson in the early stages, which must be practiced. However, following the general pattern, more devotion is devoted to Balinese rituals. According to Balinese terms, religious ceremonies must be based on tattwa (philosophy). So religious traditions are not only viewed from the splendor and splendor of their appearance. Still, they must be based on an understanding of the meaning and meaning behind the holding of the religious ceremony.

In applying the teachings of devotional service, the Bhujangga Vaishnavas cannot be separated from jnana because Bhujangga also means a teacher, advisor to the King, and a literary expert. They are required to have high knowledge and abilities (Surpi et al. 2020). This indicates that the citizens of Bhujangga are "nyastra" citizens or also called experts in the field of literature, even called poets. In the Bhujangga Vaishnava tradition, the bhakti doctrine is related to the worship performed by the sulinggih and the Bhujangga residents, the concept of puja in the Bhujangga Vaishnava ritual. In addition, the vision of Ida Rsi Bhujangga Waisnawa is like water that can prosper humankind. So water (Vișnu) is the essence of all living beings. Bhakti is mind-modifying, whereas Brahma-jñāna is self-luminous, losing all kinds of ātman modifications (Saha 2019).

The word Bhujangga and the word Vaishnava have the same meaning: understanding divinity to reach God in the form of Vișnu or Narayana. Because the worship of Vișnu is the essence of Viṣnu is also the goal, 
which means very close to the Vaisnava doctrine that the highest goal is to unite with Visnu (Surpi 2020b). As opinion (Edelmann 2012) that the discussion of Hindu teachings in various fields will meet the meeting point of theology and philosophy for now and in the future. That dialogue in philosophy and theology makes science progress, builds a minimal life with conflict, and creates a good spirit towards a harmonious and tolerant society.

\section{CONCLUSION}

Vaișnava divine philosophy is an old tradition in the discourse of religious philosophy about the search for the highest Reality in the Hindu philosophical system, namely Vedānta. Vaișnava divinity is essentially an attempt to find the ultimate Reality as the ontology of Brahman. The old Vaișnava tradition rooted in the Sacred Vedas was given a new interpretation by several saints, teachers, and philosophers such as Rāmānujacharya, Madhācharya, Vallabhācarya, and Caitanya Mahaprabhu. Each of these great thinkers came up with their thoughts on the ultimate Reality in the Vaișnava-bhakti tradition, hence the name Vaisnava Philosophy in the sub-system of Vedanta. The meeting point of the Vaisnava Divine Philosophy is that the highest truth is Sentient Being, where Brahman is the Supreme Person. The difference in thinking lies in the attributes of Brahman. The relationship between Brahman and Jiva, Brahman and the creation of the universe, and the doctrine of mokșa.

The arrival of Vaisnnava teachings in Southeast Asia is related to the history of Hindu influence. Scientists argue India exerted influence in Southeast Asia estimated at two centuries BC. The contact was allegedly carried out by traders, sailors, sailors, and travelers (travelers, explorers). Sanskrit has experienced cosmopolitan Sanskrit, where this language dominates the existence of manuscripts and inscriptions in Southeast Asia and other letters such as Tamil and Pallava. Vaișnava teachings dominated royal religion from the 1st to the 7th centuries in Southeast Asia, including the Archipelago. King Arlangga is one of the kings who is famous as a follower of Vișnu in Indonesia. Symbols associated with Vaișnava are widely distributed in historical remains, such as the Garuda reliefs on several temples. This strong influence caused Garuda to be chosen as the Symbol of the Unitary State of the Republic of Indonesia. The highest reality doctrine is interpreted as the essence in the tradition of thinking of the Maha Warga Bhujangga Vaishnavas in Bali. That Vișnu is worshiped as the essence through bhakti-yoga. This doctrine is understood to be similar to the Vaisnava divine philosophy doctrine. However, in its implementation, its embodiment follows the religious pattern in Bali, but the Vaishnava style is still visible, and worship is at the level of nature. Bhujangga Vaishnavas also have the same pattern, namely Vaiṣnava teachings incognito with local traditions, customs, and Balinese culture.

Hindu divinity, in general, uses theological and philosophical approaches simultaneously and does not contradict the two. According to the more satisfying typology to their hearts, people can study divinity through theology or philosophy. Likewise, the Vaișnava Godhead, which is part of the Vedānta, can be approached in the realm of philosophy and theology. However, in describing the Vaisnava divinity, the authors use a philosophical approach or theo-philosophy because reason and knowledge are considered more acceptable. Dialogue in the realm of theology and philosophy is essential today. Understanding God at the level of nature will encourage people to naturally build a spirit of mutual respect to create a harmonious life amid different doctrines.

\section{References}

Aryadharma, Ni Kadek Surpi. 2019. Vedānta \& Metode Pemahaman Filsafat Hindu. Surabaya: Paramita.

Chano, Jiraporn, and Ni Kadek Surpi. 2020. "The Thoughts on Divinity Philosophy of Madhvācarya." Vidyottama Sanatana International Journal of Hindu Science and Religious Studies 4(2):250-60.

Chari, S. M. Srinivasa. 2000. Vaișnavism Its Philosophy, Theology and Religious Discipline. Delhi: Motilal Banarsidass Publishers. 
Chaudhuri, Haridas. 1954. "The Concept of Brahman in Hindu Philosophy." Philosophy East and West $4(1): 47$.

Edelmann, Jonathan. 2015. "The Cause of Devotion in Gaudiya Vaisnava Theology: Devotion (Bhakti) as the Result of Spontaneously \{yadrcchaya) Meeting a Devotee (Sadhu-Sanga)." Journal of the American Oriental Society.

Edelmann, Jonathan B. 2012. "The Role of Hindu Theology in the Religion and Science Dialogue." Zygon 47(3).

Gupta, Ravi M. 2007. The Chaitanya Vaishnava Vedanta of Jiva Gosvami: When Knowledge Meets Devotion.

Hamka. 2016. Lembaga Budi. Yogyakarta: Republika Penerbit.

Hamka. 2017. Falsafah Ketuhanan. Jakarta: Gema Insani.

Harshananda, Swami. 2009. The Six System of Hindu Philosophy A Primer. Chennai: Ramakrishna Math.

Hidayat, Nanang R. 2009. Mencari Telur Garuda. Jakarta: Nalar.

KadekSurpi, Ni. 2021. "Hindu Literacy: The Basic Concept of Education and the Literacy Patter in Upanisads.” KnE Social Sciences 2021:86-96.

Knapp, Stephen. 1992. The Universal Path to Enlightenment: The Eastern Answers to the Mysteries of Life Volume II. Michigan: The World Relief Network.

Leahy, L. 1993. Filsafat Ketuhanan Kontemporer. Yogyakarta: Kanisius.

Long, Jeffery D. 2012. "Unifying Hinduism: Philosophy and Identity in Indian Intellectual History - By Andrew J. Nicholson." Religious Studies Review.

Manguin, Pierre-Yves. 2004. "The Archaeology of Early Maritime Polities of Southeast Asia." Southeast Asia: From Prehistory to History (January 2004).

Mohanty, J. N. 2018. "Philosophy of Logic.” Journal of Indian Council of Philosophical Research.

Munoz, Paul Michel. 2013. Kerajaan-Kerajaan Awal Kepulauan Indonesia Dan Semenanjung Malaysia (Early Kingdoms of the Indonesian Archipelago and the Malay Peninsula). Yogyakarta: Media Abadi.

Patra, Benudhar. 2014. "Kalinga and China: A Study in Ancient Relations.” Odisha Review, 46-50.

Pollock, Sheldon. 1996. "The Sanskrit Cosmopolis, 300-1300: Transculturation, Vernacularization and the Question of Ideology." Pp. 197-247 in Ideology and status of Sanskrit. Contribution to the history the Sanskrit Language, edited by J. E. M. Houben. Leiden: E.J. Brill (Brill's Indological Library).

Radhakrishnan, S. 1924. The Philosophy of the Upanisads. London: George Allen \& Unwin Ltd.

Radhakrishnan, Sarvepalli. 1953. The Principal Upanishads. London: George Allen \&Unwin LTD.

Ricoeur, Paul. 2012. Teori Interpretasi. Yogyakarta: IRCiSoD.

Saha, Niranjan. 2019. "Saguna and Nirguna-Bhakti, Advaita Vedanta and Madhusudana Sarasvati." Journal of Vaishnava Studies 28.

Sharan, Mahesh Kumar. 2003. Studies in Sanskrit Inscriptions of Ancient Cambodia. India: Abhinav Publications.

Sivananda, Swami. 1998. All About Hinduism. Uttar Pradesh: A Divine Life Society Publication. 
Smith, Frederick M., Patrick Olivelle, and Valerie J. Roebuck. 2002. "The Early Upanisads: Annotated Text and TranslationThe Upanisads." Journal of the American Oriental Society.

Steinkellner, Ernst, and Ruth Reyna. 1973. "Introduction to Indian Philosophy." Journal of the American Oriental Society.

Stoker, Valerie. 2007. "Vedic Language and Vaisnava Theology:Madhva's Use of Nirukta in His Rgbhāsya." Journal of Indian Philosophy.

Surpi A, Ni Kadek. 2020. "Metode Ilmu Pengetahuan Hindu." P. 87 in Paradigma Keilmuan Hindu Kemampuan para Intelektual Mengeksplorasi Ajaran Veda. Surabaya: Brilian International.

Surpi, Ni Kadek. 2019. “Ketuhanan Vaișnava Dan Pemaknaannya Oleh Warga Bhujangga Waisnawa Di Bali." Disertasi Institut Hindu Dharma Negeri Denpasar, Denpasar.

Surpi, Ni Kadek. 2020a. "Konsep Monoteisme Dalam Rgveda (Kajian Konsep Ketuhanan Hindu Perspektif Vedic Hermeneutic)." Vidya Darśan 2(1):31-35.

Surpi, Ni Kadek. 2020b. "Śivagrha (Prambanan Temple) as an Archetype of Hindu Theology in Nusantara (An Endeavor to Discover Hindu Theological Knowledge through Ancient Temple Heritage)." Analisa: Journal of Social Science and Religion 5(01).

Surpi, Ni Kadek, Ni Nyomanayu Nikki Avalokitesvari, I. Ketut Ardana, I. Ketut Sukanta, and I. Dewa Made Subrata. 2020. "The Divinity Philosophy of VaiȘNava and Its Interpretation by the Warga Bhujangga Waisnawa in Bali." International Journal of Advanced Science and Technology.

Surpi, Ni Kadek, and I. Komang Dian Adi Purwadi. 2021. "Konsep Dasar Literasi Dalam Upani ș Ad Sebagai Upaya Peningkatan Mutu Pendidikan." Jurnal Penelitian Agama Hindu 7.

Surpi, Ni Kadek, I. Gusti Putu Gede Widiana, and I. Made Wika. 2021. "Indian Logic (Ānvīkșikī) As The Light Of Knowledge And Its Relevance To The Learning Of Hindu Philosophy Nowadays." Vidyottama Sanatana International Journal of Hindu Science and Religious Studies V(1).

Suseno, Franz Magnis. 2007. Manalar Tuhan. Yogyakarta: Kanisius.

Tapasyānanda, Swami. 2010. Bhakti Schools of Vedānta: Lives and Philosophies of Rāmānuja, Nimbārka, Madhva, Vallabha and Caitanya. Madras: Sri Ramakrishna Math.

Tjahjadi, Simon Petrus Lili. 2007. Tuhan Para Filsuf Dan Ilmuwan Dari Descartes Sampai Whitehead. Yogyakarta: Kanisius.

Venkatesan, Archana. 2018. "Caitanya Vaișava Philosophy: Tradition, Reason and Devotion, Edited by Ravi M. Gupta. Dorchester, UK: Ashgate, 2014. Viii + 244 Pp., \$153.00 (Hb), \$54.95 (Pb). ISBN 9780754661771 (Hb), 978-1-138-24885-4 (Pb)." Religions of South Asia 11(1).

Vireśvarānanda, Svāmi. 2002. Brahma Sūtra Pengetahuan Tentang Ketuhanan. Surabaya: Paramita. 